\title{
Original article (short paper) \\ Novel equations to predict body fat percentage of Brazilian professional soccer players: A case study
}

\author{
Luiz Fernando Novack \\ Guilherme Assunção Ferreira \\ Rogerio Luz Coelho \\ Raul Osiecki \\ Federal University of Paraná, Brazil
}

\begin{abstract}
This study analyzed classical and developed novel mathematical models to predict body fat percentage $(\% \mathrm{BF})$ in professional soccer players from the South Brazilian region using skinfold thicknesses measurement. Skinfolds of thirty one male professional soccer players (age of $21.48 \pm 3.38$ years, body mass of $79.05 \pm 9.48 \mathrm{~kg}$ and height of $181.97 \pm 8.11 \mathrm{~cm}$ ) were introduced into eight mathematical models from the literature for the prediction of \%BF; these results were then compared to Dual-energy X-ray Absorptiometry (DXA). The classical equations were able to account from $65 \%$ to $79 \%$ of the variation of $\%$ BF in DXA. Statistical differences between most of the classical equations (seven of the eight classic equations) and DXA were found, rendering their widespread use in this population useless. We developed three new equations for prediction of $\% \mathrm{BF}$ with skinfolds from: axils, abdomen, thighs and calves. Theses equations accounted for $86.5 \%$ of the variation in $\% \mathrm{BF}$ obtained with DXA.
\end{abstract}

Keywords: dual-energy X-ray Absorptiometry (DXA), body mass, skinfold thicknesses

Resumo - "Equações para predição de novo percentual de gordura corporal de jogadores brasileiros profissionais de futebol: Um estudo de caso." O objetivo do estudo foi analisar e desenvolver novas equações para predição do percentual de gordura corporal $(\% \mathrm{G})$ em atletas profissionais de futebol do sul do Brasil usando medidas de dobras cutâneas. Dobras cutâneas de trinta e um atletas profissionais de futebol do sexo masculino (idade de 21,48 $\pm 3,38$ anos, massa corporal de $79,05 \pm 9,48 \mathrm{~kg}$ e estatura de $181,97 \pm 8,11 \mathrm{~cm}$ ) foram aplicadas em oito modelos matemáticos existentes na literatura para predizer o $\% \mathrm{G}$ e comparados com valores de $\% \mathrm{G}$ obtidos pela absortometria de raios-X de dupla energia (DXA). As equações clássicas levaram em conta 65 a $79 \%$ da variação do \%G no DXA. Foram encontradas diferenças significativas entre sete das oito equações clássicas e DXA. Foram desenvolvidas três novas equações para predição do \%G usando as dobras: Axilar, abdominal, coxa, e panturrilha. Estas equações levaram em conta $86,5 \%$ da variação do \%G do DXA.

Palavras-chave: absortometria de raios-X de dupla energia, massa corporal, dobras cutâneas

Resumen - "Ecuaciones nuevas para predecir el porcentaje de grasa corporal de los jugadores brasileños profesionales de fútbol: Un estudio de caso." El objetivo de este estudio fue analizar las ecuaciones clásicas y nuevos modelos matemáticos para predecir el porcentaje de grasa corporal (\% bf) en el futbolista brasileño del sur, utilizando espesores mediciones de pliegues cutáneos. Los bordes/ pliegues cutáneos de 31 jugadores hombres de fútbol profesional (edad de $21,48 \pm 3,38$ años, la masa corporal de 79,05 $\pm 9,48 \mathrm{~kg}$ y altura de $181.97 \pm 8.11 \mathrm{~cm}$ ) se introdujeron en ocho modelos matemáticos de literatura para la predicción del\% BF; estos resultados fueron comparados con los rayos X de energía dual absorciometría (DXA). Las ecuaciones clásicas fueron capaces de dar cuenta del $65 \%$ al $79 \%$ de la variación del $\%$ BF en DXA. No se encontraron diferencias estadísticas entre la mayor parte de las ecuaciones clásicas (es decir, siete de ocho ecuaciones clásicas) y DXA, haciendo su uso generalizado en esta población sea inútil. Nosotros sugerimos tres nuevas ecuaciones para la predicción del\% BF con pliegues desde: axilas, abdomen, muslos y la pantorrilla. Estas ecuaciones representaron el $86,5 \%$ de la variación en $\%$ GC obtenidos con DXA.

Palabras clave: energía dual de rayos X absorciometría, la masa corporal, pliegues cutáneos 


\section{Introduction}

Soccer is one of the most popular sports in the world. It requires a high level of physical fitness (Tonnessen, Hem, Leirstein, Haugen, \& Seiler, 2013) and a low percentage of body fat (Casajus, 2001; Nikolaidis, 2012; Wittich, Oliveri, Rotemberg, \& Mautalen, 2001). The evaluation of body composition reflects the changes in the athlete's body during a competitive season and, therefore, is a key component in monitoring interventions of a training program (Carling \& Orhant, 2010; Egan, Wallace, Reilly, Chantler, \& Lawlor, 2006; Sutton, Scott, Wallace, \& Reilly, 2009). Several methods have been developed to assess body composition (Ackland et al., 2012). Field techniques using skinfold measurement for estimates of body fat percentage $(\% \mathrm{BF})$ by mathematical models are widely used, mainly due to their low operating cost and easy applicability. These equations are of a major interest in exercise physiology (Eston, Rowlands, Charlesworth, Davies, \& Hoppitt, 2005; Reilly et al., 2009) and are widely used in soccer (Carling \& Orhant, 2010; Reilly et al., 2009).

There are some limitations on the use of the more general equations for body composition in athletes (Silva, Fields, Quiterio, \& Sardinha, 2009). Most studies proposing equations to estimate $\% \mathrm{BF}$ were conducted with non-athletes or differ in population profile (e.g., sex, age ethnicity), very few studies were done primarily on soccer players (Reilly et al., 2009). Reilly et al. (2009) showed that the equations often used to evaluate body composition of soccer players overestimate the $\% \mathrm{BF}$, demonstrating the inaccuracy of classical mathematical models in these athletes. Most of the mathematical models proposed in the literature were validated by comparisons with hydro-densitometry (also called hydrostatic weighting), which uses general population tables for its calculations; but athletes have high levels of muscle mass and bones density, and this can highly affect hydro-densitometry accuracy (Egan et al., 2006). Additionally, the existent equations, per se, are not good predictors of \%BF for athletes (Silva et al., 2009).

Currently, the availability of more precise and technologically validated devices such as Dual Energy X-ray Absorptiometry (DXA) have become the gold standard in body composition analysis, even among soccer players (Amaral et al., 2011; Ball, Altena, \& Swan, 2004; Carling \& Orhant, 2010; Egan et al., 2006; Eston et al., 2005; Reilly et al., 2009). However, DXA is of low practical applicability in the daily training and planning of professional athletes, since its costly and technically demanding.

Reilly et al. (2009) have suggested equations for predicting $\% \mathrm{BF}$ in soccer players. The authors observed that their equation accounted for $78.4 \%$ variance in DXA values and therefore were good predictors of body fat in soccer players. According to their findings, it is plausible that their equations could be extrapolated to Brazilian soccer players and that the classical equations could under or overestimate body fat in these athletes also. To our knowledge, no studies were conducted with Brazilian soccer players from the South region of Brazil that compare existing methods of using skinfold data with DXA or development of specific equations for $\% \mathrm{BF}$ in this population. Therefore, it is important to determine whether the existing equations and mathematical models proposed by Reilly et al. (2009) are good predictors of the $\% \mathrm{BF}$ in Brazilian professional soccer players; this could also lead to the development of novel equations for prediction of $\% \mathrm{BF}$ in this specific population.

The assessment of body composition provides important information about the training status of the athlete and is strongly associated with performance. The use of inappropriate equations could determine inaccurate body composition profiles, and ultimately interfere with the planning and interpretation of the effect of training on anthropometric variables (Withers, Craig, Bourdon, \& Norton, 1987).

The objective of this study was comparing classical and novel mathematical models for predicting $\% \mathrm{BF}$ by skinfold measurement in a group of professional soccer players from the South Brazilian region. For these purposes we used as gold standard $\%$ BF measured through DXA. This study provides information on the validity and practical use of existing equations in the literature for the prediction of body fat when compared to the gold standard DXA. We also provide the stepwise building and the advantages of our novel equations for the $\% \mathrm{BF}$ assessment of skinfolds of Brazilian professional soccer players.

\section{Methods}

\section{Participants}

Thirty-one male professional soccer players (age $21.48 \pm$ 3.38 years, body mass $79.05 \pm 9.48 \mathrm{~kg}$ and height of $181.97 \pm$ $8.11 \mathrm{~cm}$ ) all members of the three major football clubs in the city of Curitiba, South region of Brazil, were non-randomly selected to participate in this study. All had at least 5 years of professional experience and endured regular training of 6 to 8 weekly sessions. The training sessions were divided into two training sessions per day involving physical training, specific technical and tactical modalities. We chose athletes that were active members of their clubs' major teams for national competitions recognized by the Brazilian Football Confederation (CBF). We conducted a prior pilot study with a sample consisted of 20 male soccer players (age $18.96 \pm 0.88$ years, body mass $70.47 \pm 7.43 \mathrm{~kg}$ and height of $179.48 \pm 6.66 \mathrm{~cm}$ ) for feasibility and study design purposes.

All individuals were informed about the methodological procedures they were to be submitted and agreed to participate in the study, signed informed consent were obtained from all participants. The study was approved by the ethics committee of the Federal University of Paraná (\# CAAE 51140000 09110 , October 27, 2010).

\section{Experimental design}

Skinfolds of participants were obtained and compared to DXA measurements. Skinfolds measurements were applied in existing equations for predicting $\% \mathrm{BF}$ and subsequently compared with that observed by DXA. New equations from these skinfolds were found both by forward and backward stepwise multiple regression analysis. 


\section{Anthropometry}

The same experienced research assistant performed all the anthropometric measurements. Technical Error of Measurement (TEM) for the examiner of these anthropometric measures was calculated in the pilot study with a sample of similar profile, following the proposed technique by Perini et al. (Perini, Oliveira, Ornellas, \& Oliveira, 2005).

The Absolute Technical Error of Measurement was calculated in three steps: 1) Determining the difference between the measurements for each anthropometric point (deviations); 2) Deviations in each anatomical point were squared; 3$)$ Results of the second stage were added $\left(\Sigma \mathrm{d}^{2}\right)$ and absolute TEM was obtained by the equation below, where $\sum \mathrm{d}^{2}$ is the summation of deviations squared, and $\mathrm{n}$ is number of athletes measured.

$$
\text { Absolute TEM }=\sqrt{\frac{\sum d^{2}}{2 n}}
$$

Skinfolds measurements that showed values below 5\% of TEM were classified as acceptable. Mitsubishi 7600 and Harpenden skinfold calipers (Cranlea, Birmingham, UK) were used. Height, body mass and skinfold measurements were taken according to procedures proposed by Lohmann, Roche, and Martorell (1988). Nine skinfold thicknesses, (chest, triceps, biceps, subscapular, midaxillary, suprailiac, abdominal, medial thigh and medial calf) were obtained.

The classical equations asked for measurements obtained from the above anatomical points (although not all of these equations used all of these measures), so they were all obtained for each participant. The intermediate value of three consecutive measurements for each skinfold was used. If these three measurements varied by more than $\pm 5 \%$ a new series of three measurements was performed (Ball et al., 2004).

The new prediction equations were derived from skinfold of all 31 soccer players. The data was applied to a series of equations found in the literature for predicting body fat (Table 1). In equations $1-5$, originally validated by the method of hydrostatic weighing, density values were converted to body fat percentage $(\% \mathrm{BF})$ using the fowling equation by (Siri, 1993):

$$
\% B F=\left(\frac{4.95}{\text { body density }}\right) \cdot 100
$$

\section{Dual Energy X-ray Absorptiometry (DXA)}

All participants underwent whole body scan by DXA (GE Medical Systems, Lunar, Prodigy, Madson, WI, emCore software version 8.50.093). Prior to the exam, they were asked about current injuries, orthopedic pins or implants and were then instructed to remove all metallic objects from the body (jewelry, watches, belts, etc). The exam was conducted with subjects
Table 1. Equations in the literature to predict body fat (author, method, equation, correlation coefficient, coefficient of determination, standard

\begin{tabular}{|c|c|c|c|c|c|}
\hline & Author & Method & $R$ & $r^{2}$ & SE \\
\hline 1 & $\begin{array}{c}\text { Durnin and } \\
\text { Womersley (1974) }\end{array}$ & Hidrostatic & - & - & $0.0103 \mathrm{~g} . \mathrm{cm}^{-3}$ \\
\hline 2 & $\begin{array}{c}\text { Jackson and Pollock } \\
\text { (1978) }\end{array}$ & Hidrostatic & .90 & - & $0.0078 \mathrm{~g} \cdot \mathrm{cm}^{-3}$ \\
\hline 3 & $\begin{array}{c}\text { Jackson and Pollock } \\
\text { (1978) }\end{array}$ & Hidrostatic & .90 & - & $0.0077 \mathrm{~g} . \mathrm{cm}^{-3}$ \\
\hline 4 & Lohman (1981) & Hidrostatic & .92 & - & $0.0071 \mathrm{~g} . \mathrm{cm}^{-3}$ \\
\hline 5 & Withers et al. (1987) & Hidrostatic & - & - & - \\
\hline 6 & Eston et al. (2005) & DXA & .80 & .79 & $1.8 \%$ \\
\hline 7 & Eston et al. (2005) & DXA & .70 & .67 & $2.5 \%$ \\
\hline 8 & Reilly et al. (2009) & DXA & & .78 & - \\
\hline
\end{tabular}
error of estimate) the statistics were reported in the original studies.

Hydrostatic $=$ Hydrostatic Weighting (also called Hydro-densitometry); DXA $=$ Dual Energy X-ray Absorptiometry; $r=$ correlation coefficient; $r^{2}=$ determination coefficient; $\mathrm{SE}=$ standard error of estimate.

lying in the supine position, with arms and legs slightly apart. All scans were performed by the same radiology technician.

\section{Statistical analysis}

We tested the data with the Shapiro-Wilk test, and normality was accepted. Each equation's \%BF estimate was treated as a variable that was correlated to the $\% \mathrm{BF}$ obtained in DXA $\left(\% \mathrm{BF}_{\mathrm{DXA}}\right)$. The Technical Error (TEM) of measurements was calculated. The skinfolds that showed values below $5 \%$ of TEM were classified as acceptable (Perini et al., 2005). We then produced new formulas for estimating body fat by a stepwise multiple regression technique (both forward and backward). The dependent variable was the $\% \mathrm{BF}_{\mathrm{DXA}}$, and the independent

Table 2. The mean values, standard deviation, minimum and maximum values, and the correlation to body fat percentage obtained by DXA

\begin{tabular}{|c|c|c|c|c|}
\hline Skinfolds (mm) & Mean \pm SD & Minimum & Maximum & $\mathrm{r} \% \mathrm{BF}_{\mathrm{DXA}}$ \\
\hline Chest & $6.34 \pm 2.07$ & 3.20 & 10.80 & $.74^{*}$ \\
\hline Biceps & $4.20 \pm 1.00$ & 2.80 & 7.00 & $.68^{*}$ \\
\hline Subscapular & $9.30 \pm 2.27$ & 5.80 & 17.60 & $.56^{*}$ \\
\hline Triceps & $7.70 \pm 2.17$ & 4.20 & 12.80 & $.68^{*}$ \\
\hline Midaxillary & $8.19 \pm 2.23$ & 4.40 & 13.60 & $.76^{*}$ \\
\hline Supra iliac & $11.92 \pm 4.49$ & 5.80 & 27.40 & $.68^{*}$ \\
\hline Abdomen & $12.24 \pm 4.62$ & 5.60 & 21.40 & $.80^{*}$ \\
\hline Anterior thigh & $9.53 \pm 2.81$ & 4.80 & 16.60 & $.75^{*}$ \\
\hline Medial calf & $6.28 \pm 2.02$ & 3.80 & 14.00 & $.61 *$ \\
\hline \multicolumn{5}{|l|}{ DXA } \\
\hline $\begin{array}{l}\text { Body Fat } \\
\text { Percentage (\%) }\end{array}$ & $13.68 \pm 4.22$ & 6.10 & 22.40 & \\
\hline Fat Mass (kg) & $10.99 \pm 4.06$ & 3.90 & 20.60 & \\
\hline Fat Free Mass $(\mathrm{kg})$ & $68.05 \pm 7.38$ & 51.98 & 85.00 & \\
\hline
\end{tabular}
$\left(\mathrm{r} \% \mathrm{BF}_{\mathrm{DXA}}\right)$ and skinfolds. 
Table 3. Novel equations proposed to predict body fat in professional soccer players.

\begin{tabular}{|c|c|c|c|c|c|c|}
\hline & Method & Equation & $r$ & $r^{2}$ & $r_{\mathrm{a}}^{2}$ & SE \\
\hline 1 & Linear Forward & $(0.83196071 \cdot \mathrm{MA})+(0.16367624 \cdot \mathrm{AB})+(0.75492553 \cdot \mathrm{AT})-2.33295828$ & $.925^{\dagger}$ & .856 & .839 & 1.690 \\
\hline 2 & Linear Backward & $\left(0.67901792 \cdot \Sigma_{2 \mathrm{SKF} 1}\right)+\left(0.07619429 \cdot \Sigma_{2 \mathrm{SKF} 2}\right)+\left(0.06801188 \cdot \Sigma_{4 \mathrm{SKF}}\right)-2.37873851$ & $.925^{\dagger}$ & .856 & .840 & 1.689 \\
\hline 3 & Linear Backward & $\left(0.75055662 \cdot \Sigma_{2 \mathrm{SKF} 1}\right)+\left(0.13910823 \cdot \Sigma_{2 \mathrm{SKF} 2}\right)-2.46345040$ & $.925^{\dagger}$ & .865 & .845 & 1.662 \\
\hline
\end{tabular}

$\mathrm{MA}=$ midaxillary; $\mathrm{AB}=$ abdominal; $\mathrm{AT}=$ anterior thigh $; \Sigma_{2 \mathrm{SKF} 1}=$ midaxillary plus anterior thigh; $\Sigma_{2 \mathrm{SKF} 2}=$ midaxillary plus abdominal; $\Sigma_{4 \mathrm{SKF}}=$ chest plus abdominal plus midaxillary; $r=$ multiple correlation coefficient; $r^{2}=$ determination coefficient; $r_{a}^{2}=$ adjusted determination coefficient; $S E=$ adjusted coefficient; ${ }^{\dagger}$ Denotes nearly perfect correlations.

variables were combinations and sums of skinfolds. We did the following steps proposed for Lohmann et al. (1988) to obtain the best fit in regression analysis: 1) Use of skinfolds alone; 2) Use of different skinfold summations; 3) use of different combinations of skinfold summations; 4) Inclusion of the quadratic skinfold alone plus different skinfold summations.

We chose mathematical models that had: 1) high significance of partial variables; 2 ) correlation coefficient greater than 0.89 $(r>.89) ; 3)$ coefficient of determination greater than $0.80\left(r^{2}>\right.$ $.80)$; 4) standard error of estimate less than $2.0(\mathrm{EPE}<2.0)$ and $5)$ normality of residue verified by the Shapiro-Wilk test. The classification of correlation was calculated and interpreted as proposed by Hopkins (2013) (http://www.sportsci.org/resource/ stats/effectmag.html) $\leq .1$ trivial; $>.1$ and $\leq .2$ small; $>.3$ and $\leq$ .5 moderate; and $>.5$ and $\leq .7$ large; and $>.7$ and $\leq .9$ very large; and $>.9$ nearly perfect; and $\leq 1.0$ perfect. Statistical analysis were conducted with SPSS version 18 (SPSS, Chicago, IL), and all significance levels were considered as $p<.05$.

\section{Results}

The mean values, standard deviation, minimum and maximum values, and the correlation to $\% \mathrm{BF}_{\mathrm{DXA}}$ for skinfold are shown in Table 2. All skinfold measurements had high significance for correlation with $\% \mathrm{BF}_{\mathrm{DXA}}(p<.01)$.

Table 4 . The values for body fat percentage $(\% \mathrm{BF})$ and relationships between the different equations and body fat percentage by DXA $\left(\% \mathrm{BF}_{\mathrm{DXA}}\right)$.

\begin{tabular}{llcccc}
\hline & \multicolumn{1}{c}{$\mathbf{\% B F}$} & $\boldsymbol{r}$ & $\boldsymbol{r}^{\mathbf{2}}$ & $\mathbf{B i a s}$ \\
\hline & DXA & $13.68 \pm 4.22$ & & - & - \\
1 & $\begin{array}{l}\text { Durnin and Womersley } \\
\text { (1974) }\end{array}$ & $15.09 \pm 3.47+$ & $.81^{* \dagger \dagger}$ & .65 & 1.42 \\
2 & & & & \\
& $\begin{array}{l}\text { Jackson and Pollock } \\
\text { (1978) }\end{array}$ & $8.38 \pm 2.80^{+}$ & $.85^{* \dagger \dagger}$ & .73 & 5.30 \\
3 & Jackson and Pollock & $8.05 \pm 3.02+$ & $.88^{* \dagger \dagger}$ & .77 & 5.63 \\
& (1978) & & & & \\
4 & Lohman (1981) & $7.48 \pm 1.01^{+}$ & $.86^{* \dagger \dagger}$ & .74 & 6.20 \\
5 & Withers et al. (1987) & $10.49 \pm 2.46^{+}$ & $.91^{* \dagger}$ & .83 & 3.19 \\
6 & Eston et al. (2005) & $12.82 \pm 2.51$ & $.83^{* \dagger \dagger}$ & .69 & 0.86 \\
7 & Eston et al. (2005) & $12.75 \pm 2.75^{+}$ & $.88^{* \dagger \dagger}$ & .77 & 0.94 \\
8 & Reilly et al. (2009) & $10.48 \pm 1.41^{+}$ & $.89^{* \dagger \dagger}$ & .79 & 3.20 \\
\hline
\end{tabular}

+ Significantly differs from DXA $(p>.05)$; * significant correlation with $\% \mathrm{BF}_{\mathrm{DXA}}, p<.001 ;{ }^{\dagger}$ Denotes nearly perfect correlations; ${ }^{\dagger}$ Denotes very large correlations.
The new formulas proposed and their statistics are presented in Table 3. These new equation, that are more specific, explained the change in $\% \mathrm{BF}$ better, with adjusted determination coefficient $\left(r_{\mathrm{a}}^{2}\right)$ of up to .845 . Each equation uses a combination of different skinfolds: Equation 1 (midaxillary, medial abdominal and anterior thigh); Equation 2 (midaxillary, medial abdominal, calf and anterior thigh) and Equation 3 (midaxillary, thigh and medial and anterior abdominal).

Significant correlations ( $r=.81$ to .91$)$ between all classical equations and DXA were observed. The statistics for $\% \mathrm{BF}$ calculated by these equations are described in Table 4. The only classical equation that did not differ statistically from DXA was number 6, proposed by Eston et al. (2005) and DXA. Equation 1 overestimated and equations 2, 3, 4, 5, 7 and 8 underestimated the value of $\%$ BF when compared to DXA (Table 4).

\section{Discussion}

We examined existing and proposed novel equations for prediction \% $\mathrm{BF}$ in Brazilian soccer players. Generally the classical equations were based on athletes from different countries or modalities and non-athlete populations (Ackland et al., 2012; Amaral et al., 2011; Ball et al., 2004; Bracco et al., 1996; Reilly et al., 2009). Our professional soccer players sample was comparable to those observed in previous studies: Reilly et al. (2009) and Sutton et al. (2009) with British athletes (182.0 $\pm 0.07 \mathrm{~cm}$ height and body weight $82.0 \pm 8.5 \mathrm{~kg}, 83.2$ $\pm 7.5 \mathrm{~kg}$, respectively); Wittich et al. (2001) with Argentine athletes (height $=176.8 \pm 4.5 \mathrm{~cm}$ and body mass $76.2 \pm 5.4 \mathrm{~kg}$ ), Silvestre et al. (2006) in a study of American college soccer players (height $=177.6 \pm 6.4 \mathrm{~cm}$, body mass $=77.6 \pm 8.6 \mathrm{~kg}$ ); and Clark (2007) with South African athletes (height $=176.3$ $\pm 7.1 \mathrm{~cm}$, body mass $=73.7 \pm 9.1 \mathrm{~kg}$ ). Nonetheless our values were below those found by Reinke et al. (2009) with German league players (height $184.2 \pm 5.9 \mathrm{~cm}$ and body mass $90.1 \pm$ $5.6 \mathrm{~kg})$. The observed values of the DXA in our study $(13.68 \pm$ $4.22 \% \mathrm{BF}$ ) are consistent with those found in the literature for soccer players: Reilly et al. (2009) (11.2 $\pm 1.8 \%$ BF ), Reinke et al. (2009) (11.9 $\pm 6.2 \% \mathrm{BF})$, Wittich et al. (2001) $(13.6 \pm 3.3$, $11.1 \pm 2.8$ and $11.0 \pm 2.3 \% \mathrm{BF})$, Silvestre et al. (2006) (12.8 $\pm 5.2 \% \mathrm{BF})$, Clark $(2007)(13.3 \pm 3.5 \% \mathrm{BF})$ and Mero et al. (2010) $(14.1 \pm 3.9 \% \mathrm{BF})$. When we applied our data to those studies that compared skinfold equations with the gold standard DXA we found that our novel models had higher determination coefficients. Models proposed by Reilly et al. (2009) (Equation 8 in Table 1) explained $79 \%$ of the variation of $\% \mathrm{BF}$ measured 
by DXA, models by Eston et al. (2005) could explain only 79 and $67 \%$ of variation in $\% \mathrm{BF}$ with his non-athletes equations (Equations 6 and 7, respectively).

For all classical equations (Table 4), high values of determination coefficient for $\% \mathrm{BF}$ were found. The highest value being observed by the equation proposed by Withers et al. (1987) with a $r^{2}=.83$. Reilly et al. (2009) observed higher values of determination coefficient and correlation coefficient for the values obtained by the equation of Withers et al. (1987) with $\% \mathrm{BF}_{\mathrm{DXA}}\left(r=.91\right.$ and $\left.r^{2}=.83\right)$, but these values were also lower than our novel equations. The determination coefficient found for equations 2 and 3 proposed by Jackson and Pollock (1978) and 4 proposed by Lohman (1981) had $r^{2}$ equal to $.73, .77$, and .74 respectively, and were lower than the findings of the original studies $\left(r^{2}=.81 ; .81\right.$ and .85$)$. For equations 6 and 7 by Eston et al. (2005), the values found in our study for the determination coefficients were higher than those observed in previous ones $\left(r^{2}=.79\right.$ and $.67 v s . r^{2}=.64$ and .49 , respectively). These differences can be explained by differences between study populations and protocols used for validation (Ackland et al., 2012; Egan et al., 2006; Jackson \& Pollock, 2004; Wittich et al., 2001).

\section{Practical applications and future works}

Despite all the equations achieving moderate to strong correlations with DXA, they all had lower determination coefficient than the equations proposed by this study. Among the existing classical equations, one equation overestimated and 6 equations underestimated \%BF when compared to DXA. Only Equation 6 (TABLE 4) by Eston et al. (2005) did not significantly differ from DXA, but its correlation and determination coefficients were very low. In view of the need to develop more specific body fat evaluation for soccer players, all 3 novel models in this study appear better for Brazilian soccer players than the more general equations formerly published.

From a practical viewpoint, these results underline the importance of choosing the proper equation and anthropometric measurements in the clinical setting to determine body fat percentage $(\% \mathrm{BF})$ in soccer players. Although this study showed a high degree of correlation observed between these novel equations and DXA, a cross-validation was not performed. Another limitation was that athletes were not separated in different ethnical groups. Therefore, further investigations are necessary to validate the equations suggested here. Additionally, future studies addressing determination of $\% \mathrm{BF}$ in diverse ethnical groups would also be valuable.

\section{References}

Ackland, T.R., Lohman, T.G., Sundgot-Borgen, J., Maughan, R.J., Meyer, N.L., Stewart, A.D., \& Muller, W. (2012). Current status of body composition assessment in sport: review and position statement on behalf of the ad hoc research working group on body composition health and performance, under the auspices of the
I.O.C. Medical Commission. Sports Medicine, 42, 227-249. doi: 10.2165/11597140-000000000-00000

Amaral, T.F., Restivo, M.T., Guerra, R.S., Marques, E., Chousal, M.F., \& Mota, J. (2011). Accuracy of a digital skinfold system for measuring skinfold thickness and estimating body fat. British Journal of Nutrition, 105, 478-484. doi: 10.1017/s0007114510003727li

Ball, S.D., Altena, T.S., \& Swan, P.D. (2004). Comparison of anthropometry to DXA: a new prediction equation for men. [Comparative Study]. European Journal of Clinical Nutrition is a high quality, peer-reviewed journal that covers all aspects of human nutrition, 58, 1525-1531. doi: 10.1038/sj.ejcn.1602003

Bracco, D., Thiebaud, D., Chiolero, R.L., Landry, M., Burckhardt, P., \& Schutz, Y. (1996). Segmental body composition assessed by bioelectrical impedance analysis and DEXA in humans. Journal of Applied Physiology, 81, 2580-2587.

Carling, C., \& Orhant, E. (2010). Variation in body composition in professional soccer players: interseasonal and intraseasonal changes and the effects of exposure time and player position. Journal of Strength and Conditioning Research, 24, 1332-1339. doi: 10.1519/ JSC.0b013e3181cc6154

Casajus, J.A. (2001). Seasonal variation in fitness variables in professional soccer players. Journal of Sports Medicine and Physical Fitness, 41, 463-469.

Clark, J.R. (2007). higher log position is not associated with better physical fitness in professional soccer teams in south africa. American Journal of Sports Medicine, 19, 40-45.

Egan, E., Wallace, J., Reilly, T., Chantler, P., \& Lawlor, J. (2006). Body composition and bone mineral density changes during a premier league season as measured by dual-energy X-ray absorptiometry. International Journal of Body Composition Research, 4, 61-66.

Eston, R.G., Rowlands, A.V., Charlesworth, S., Davies, A., \& Hoppitt, T. (2005). Prediction of DXA-determined whole body fat from skinfolds: importance of including skinfolds from the thigh and calf in young, healthy men and women. European Journal of Clinical Nutritio, 59, 695-702. doi: 10.1038/sj.ejen.1602131

Jackson, A.S., \& Pollock, M.L. (1978). Generalized equations for predicting body density of men. British Journal of Nutrition, 40, 497-504.

Jackson, A.S., \& Pollock, M.L. (2004). Generalized equations for predicting body density of men. 1978. [Biography Classical Article Historical Article]. British Journal of Nutrition, 91, 161-168.

Lohman, T.G. (1981). Skinfolds and body density and their relation to body fatness: a review. Human Biology, 53, 181-225.

Lohmann, T.G., Roche, A.F., \& Martorell, R. (1988). Anthropometric Standardization Reference Manual: Human Kinetics Books, Champaign, Ill.

Mero, A.A., Ojala, T., Hulmi, J.J., Puurtinen, R., Karila, T.A., \& Seppala, T. (2010). Effects of alfa-hydroxy-isocaproic acid on body composition, DOMS and performance in athletes. Journal of the International Society of Sports Nutrition, 7, 1. doi: 10.1186/1550-2783-7-1

Nikolaidis, P.T. (2012). Physical fitness is inversely related with body mass index and body fat percentage in soccer players aged 16-18 years. Medicinski pregled, 65, 470-475.

Perini, T.A., Oliveira, G.L.d., Ornellas, J.d.S., \& Oliveira, F.P.d. (2005). Cálculo do erro técnico de medição em antropometria. Revista Brasileira de Medicina do Esporte, 11, 81-85.

Reilly, T., George, K., Marfell-Jones, M., Scott, M., Sutton, L., \& Wallace, J.A. (2009). How well do skinfold equations predict percent body fat in elite soccer players? International Journal of Sports Medicine, 30, 607-613. doi: 10.1055/s-0029-1202353

Reinke, S., Karhausen, T., Doehner, W., Taylor, W., Hottenrott, K., Duda, G.N., ...Anker, S.D. (2009). The influence of recovery and training phases on body composition, peripheral vascular function 
and immune system of professional soccer players. Plos One, 4, e4910-e4910. doi: 10.1371/journal.pone.0004910

Silva, A.M., Fields, D.A., Quiterio, A.L., \& Sardinha, L.B. (2009). Are skinfold-based models accurate and suitable for assessing changes in body composition in highly trained athletes? Journal of Strength and Conditioning Research, 23, 1688-1696. doi: 10.1519/ JSC.0b013e3181b3f0e4

Silvestre, R., Kraemer, W.J., West, C., Judelson, D.A., Spiering, B.A., Vingren, J.L., . . Maresh, C.M. (2006). Body composition and physical performance during a National Collegiate Athletic Association Division I men's soccer season. Journal of Strength and Conditioning Research, 20, 962-970. doi: 10.1519/r-18165.1

Siri, W.E. (1993). Body composition from fluid spaces and density: analysis of methods. 1961. [Biography Classical Article Historical Article]. Nutrition, 9, 480-491; discussion 480, 492.

Sutton, L., Scott, M., Wallace, J., \& Reilly, T. (2009). Body composition of English Premier League soccer players: influence of playing position, international status, and ethnicity. Journal of Sports Sciences, 27, 1019-1026. doi: 10.1080/02640410903030305

Tonnessen, E., Hem, E., Leirstein, S., Haugen, T., \& Seiler, S. (2013). Maximal aerobic power characteristics of male professional soccer players, 1989-2012. International journal of sports physiology and performance, 8, 323-329.

Withers, R.T., Craig, N.P., Bourdon, P.C., \& Norton, K.I. (1987). Relative body fat and anthropometric prediction of body density of male athletes. European Journal of Applied Physiology and Occupational Physiology, 56, 191-200.

Wittich, A., Oliveri, M.B., Rotemberg, E., \& Mautalen, C. (2001). Body composition of professional football (soccer) players determined by dual X-ray absorptiometry. Journal of Clinical Densitometry, $4,51-55$.

\section{Authors' note}

Luiz Fernando Novack, Guilherme Assunção Ferreira, Rogerio Luz Coelho and Raul Osiecki are affiliated with the Center for the Study of Physical Performance, Department of Physical Education, Federal University of Paraná, Curitiba, Paraná, Brazil, 80215370.

\section{Corresponding author}

Guilherme Assunção Ferreira

Department of Physical Education, Federal University of Paraná

Rua Coração de Maria, 92, Campus Jardim Botânico,

Curitiba, 80215370 PR, Brazil

Phone/fax number: +55 4188045262

E-mail: guilhermeedf@hotmail.com

Manuscript submitted on April 14, 2014

Manuscript accepted on September 24, 2014

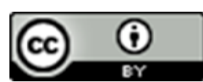

Motriz. The Journal of Physical Education. UNESP. Rio Claro, SP, Brazil - eISSN: 1980-6574 - under a license Creative Commons - Version 3.0 